\title{
Evaluation of Special Event Traffic Management: The Brickyard 400 Case Study
}

\author{
by \\ Jason S. Wasson, P.E. \\ Indiana Department of Transportation \\ Stanley E. Young \\ University of Maryland \\ Center for Advanced Transportation Technology \\ James R. Sturdevant, P.E. \\ Indiana Department of Transportation \\ Philip J. Tarnoff \\ University of Maryland \\ Center for Advanced Transportation Technology \\ Joseph M. Ernst \\ Purdue University \\ Corresponding author: \\ Darcy M. Bullock, P.E. \\ Purdue University \\ 550 Stadium Mall Dr \\ West Lafayette, IN 47906 \\ Phone (765) 496-7314 \\ Fax (765) 496-7996 \\ darcy@purdue.edu
}

August 1, 2008

TRB Paper 09-1730

Word Count: 2250 words +15 x 250 words/Figure-Table $=6000$ words

Approximate words remaining 


\section{ABSTRACT}

This paper reports on the anonymous tracking of Bluetooth enabled consumer electronic devices to measure the travel time, or space mean speed, of travelers. This sampling technique was deployed at six interstate locations and two signalized arterials in the Indianapolis, IN metropolitan area the week of the NASCAR Brickyard 400. The week prior to the race before data was also collected from a subset of those sites. The day of the race, almost 19,000 unique MAC address were captured at the eight locations. From that information real-time travel time estimates were provided to Indiana Department of Transportation (INDOT) mobile data terminals. After the race, the data was processed to obtain travel time plots and origin destination matrixes to provide a quantitative evaluation of race day traffic management operations. Selected reports and charts from that analysis are discussed in the paper.

\section{INTRODUCTION}

The Indianapolis Motor Speedway (IMS) was built as an automobile testing facility in 1909 with the first 500 mile race held in 1911. Since that time, the 2.5 mile oval track facility has evolved into a facility that seats 257,000 spectators and has over a 1 billion dollar economic impact on Indiana. The Indianapolis 500 and Brickyard 400 are attended by over 400,000 spectators, making them the two largest single day sporting events in the world.

The first efforts at managing traffic attending this facility begin in 1947 and evolved into an extensive effort involving over 700 law enforcement and transportation officials today. This paper reports on a novel travel time monitoring technique implemented for assessing and improving the race traffic management operations.

\section{TRAVEL TIME MONITORING CONCEPTS}

Travel time is one of the oldest performance measures used to characterize an arterial or freeway system. The first direct measurement of travel times were based upon license plate matching techniques (1) in vehicle notes, mechanical devices attached to odometers (2), and then Global Positioning System (GPS) recording devices (3). More recently, cell phone and toll tag tracking has been proposed as a mechanism for collecting probe vehicle link travel times $(4,6)$. A variety of statistical techniques have been published that document techniques for estimating sample size or sample proportion necessary for reliably estimating travel time $(2,6,7)$. In the past few months the tracking of consumer electronic devices has been proposed for measuring travel time across a variety of modes 
(8) by matching MAC addresses acquired from Bluetooth radios. This paper reports on the use of this technology for monitoring travel time along selected routes for spectators travelling to and from the Brickyard 400 events at the Indianapolis Motor Speedway.

\section{TRAFFIC MANAGEMENT CHALLENGES AND DATA COLLECTION}

The IMS facility is located approximately 2 miles East of the west leg of I-465 (Figure 1). Virtually the entire I-465 corridor between I-1 and I-5 (Figure 1) was an active construction zone during this study, with the segment between I-1 and I-3 having 11' travel lanes. With 400,000 fans expected, there was significant planning devoted to ensuring smooth ingress and egress as well as real-time management of INDOT facilities on race day.

Prior to the race, several permanent and temporary traffic monitoring sites were identified for collecting a variety of traffic data (Figure 1). Sites I-1, I-2, I-3, I-4 and I-5 are located along the I-465 and site I-6 is along the I-65 corridor. Both of these facilities are managed by INDOT. Sites A-1 and A-2 are located adjacent to signalized arterials in the town of Speedway adjacent to the Indianapolis Motor Speedway (IMS). These sites were selected based upon their proximity to the IMS, I-465, and expected travel patterns of motorists arriving from the North and West.

The week prior to the race (July 18-20, 2008) baseline speed and volume were collected at sites I-3 and I-6 as well as Bluetooth MAC addresses at Sites I-1, I-2, $\mathrm{I}-3, \mathrm{~A}-1$ and A-2. During race day, additional data collection sites I-4; I-5, and I-6 were deployed to acquire MAC addresses. Photographs of the monitoring equipment used to acquire MAC addresses at selected sites are shown in Figure 2. Figure $2 a$ and Figure $2 b$ show the battery powered University of Maryland data collection device installed at station A-1 adjacent to the travel lane. Figure $2 \mathrm{c}$ shows an INDOT data collection station (I-2) mounted on a wood pole. The Bluetooth antenna can be seen attached to the second ladder rung above the pole mounted cabinet in an active construction site approximately 100 feet from the nearest I-465 travel lane.

\section{VOLUME AND SPEED CHARACTERISTICS OF STUDY AREA}

Figure $3 \mathrm{a}$ and Figure $4 \mathrm{a}$ document the traffic flow rate and speed at site I-6 during the before period - July 18-20. Similarly, Figure $3 b$ and Figure $4 b$ document the traffic flow rate and speed at site I-6 during the weekend with race activity - July 18-20. The volumes figures (Figure 3a) illustrate fairly typical Friday, Saturday, Sunday characteristics the weekend prior the race. The weekend of the race (Figure $3 b$ ) one can clearly see the Southbound volume 
peaking just before noon and the strong peaking of the Northbound volume just after 1800. The speeds indicate uncongested conditions, except for a brief incident on July 25, 2008 (Figure 4b).

Figure 5 and Figure 6 follow a similar structure for characterizing site I-3. The I-3 site is in the middle of an active construction zone and as a result the volumes and speeds only reflect measurement from two of the three lanes. However, even with reduced lane sampling, Figure $5 \mathrm{a}$ and Figure $5 \mathrm{~b}$, illustrate influence the advance signing used by INDOT to direct Chicago bound traffic on I-74 and I65 to take the East leg of I-465, instead of the West leg during the Brickyard 400 event. In addition, the peaks associated with inbound and outbound to/from the IMS are clearly evident in Figure $5 \mathrm{~b}$. Figure $6 \mathrm{a}$ indicates the week prior the race had some minor variations in the speed. Figure $6 \mathrm{~b}$ show similar characteristics, but also an incident in the Southbound direction on July 25, 2008 just before 1800.

\section{TRAVEL TIME CHARACTERISTICS}

As indicated in the introduction, MAC address matching (8) was used to estimate travel time between stations identified in Figure 1. Table 1 summarizes the MAC address hits for those stations on the Sunday before the race and the Sunday of the race. Table 2 shows examples of real-time travel times computed by taking the difference between time stamps on matching MAC addresses identified at different sites. This data was available on mobile data terminals of INDOT officials managing traffic operations. This data was not filtered and allowed the display of up to three hours. This required human operators to mentally filter the data. In examining the data it is clear there are two outliers at time 19:45, 19:25, 19:10 and 18:50. The remainder of the data points are clearly in the feasible range.

In regards to post-processing of the data to analyze operations, Figure 7 illustrates the match rate by time of day between sites I-1 and I-2. Figure 8 and Figure 9 illustrate the before and after travel time for two alternative paths to the IMS. Specifically,

- Figure 8 shows the travel time for vehicles traversing the path defined by I-1; I-2; and A-1 shown on Figure 1. Positive numbers are indicative of Northbound vehicles traversing the path A-1 to I-2 to I-1. The negative numbers are indicative of Southbound vehicles traversing the path I-1 to I-2 to A-1.

- Figure 9 shows the travel time for vehicles traversing the path defined by I-1; I-2; I-3 and A-2 shown on Figure 1, following the same convention for positive and negative values for Northbound and Southbound directions, respectively.

Both of these paths span interstate and signalized arterial segments Both Figure $8 \mathrm{~b}$ and Figure $9 \mathrm{~b}$ clearly quantify the increased travel time associated with the 
incident on Friday evening as well as the increased travel times to/from stations A-1 and A-2.

Figure 10 illustrates the only large increases in travel time associated with the race. In this case, virtually all of the Northbound motorists elected to Exit at the $10^{\text {th }}$ street ramp adjacent to Station I-4, despite message signs advising them to proceed to Crawfordsville Road (Station I-3). As a result, the $10^{\text {th }}$ street arterial begin backing up on the interstate (Figure 11a) and severely restricting all Northbound traffic on I-465 (Figure 11b). INDOT dispatched a crew to temporarily close the ramp (Figure 11c) and the queuing quickly dissipated (Figure 11d).

When comparing Figure 8a with Figure $8 b$ (as well as Figure 9a with Figure 9b) it is apparent there are many more samples in the second week of data collection. This is due to the improved data collection equipment deployed at sites I-2 and I3 capable of faster MAC address acquisition and perhaps the increase in Bluetooth devices during race weekend. Also, when comparing the number of Northbound and Southbound samples in Figure $8 b$ and Figure $9 b$ the Southbound direction clearly has a larger sample size. This is most likely an artifact of the Bluetooth antennas as sites I-2 and I-3 being mounted on the West side of the interstate, thus the Southbound traffic was closest to the antenna at those sites.

\section{ORIGIN-DESTINATION CHARACTERISTICS}

In addition to collecting link data, MAC address matching can be used to estimate origin destination matrixes. Table $3 a$ shows the O-D matrix during prerace period. Table $3 b$ shows the minimum observed travel time during the prerace period and Table $3 c$ shows the average travel time during the pre-race period. Table $4 a, b$ and $c$ show the same information for the post-race period. By inspection, one can see the shift from sites adjacent to the track (sites A-1 and A2) being destinations before the race, to being origin points after the race.

\section{CONCLUSION}

This paper illustrated how MAC address tracking can be used to assess traffic management strategies used for large special events. In this case, the traffic assignment strategies developed over several years were found to work exceptionally well, with the exception of one ramp problem that was quickly addressed through established diversion practices. The larger four lane arterial servicing parking lots adjacent to station A-2 was found to work almost as well, with some brief periods of delays extending up to 10 minutes. The smaller roads and denser signal network servicing parking lots adjacent to station A-1 were observed to experience larger delays, on the order of 20 minutes for longer periods of time. 
These results indicate that there is significant promise for real-time management of special event traffic entering multiple parking lots from multiple routes, particularly for venues that do not have as mature of traffic management strategies as the Brickyard 400.

Finally, the dynamic message signs used to route I-74 and I-65 traffic around the East side of I-465 were found to be effective at reducing the Northbound through traffic on I-465 (Figure 5) on race day. A future study is planned with MAC address tracking to estimate the proportion of motorists that conform to those advisory signs.

\section{ACKNOWLEDGEMENTS}

This work was supported in part by the Indiana Department of Transportation, the University of Maryland and Purdue University. The contents of this paper reflect the views of the authors, who are responsible for the facts and the accuracy of the data presented herein, and do not necessarily reflect the official views or policies of their respective organizations. These contents do not constitute a standard, specification, or regulation. 


\section{REFERENCES}

1. Schaefer, M.C., "License Plate Matching Surveys: Practical Issues and Statistical Considerations," Institute of Transportation Engineers Journal, Volume 58, Number 7, July 1988.

2. Robertson, H., J. Hummer, and D. Nelson, "ITE Manual of Transportation Engineering Studies", Prentice Hall, 1994.

3. Quiroga, C. and D. Bullock, "Travel Time Studies with Global Positioning and Geographic Information Systems: An Integrated Methodology," Transportation Research Part C, Pergamon Pres, Vol. 6C, No. 1/2, pp. 101-127, 1998.

4. Fontaine, M.D. and B.L. Smith, "Probe-Based Traffic Monitoring Systems with Wireless Location Technology," Transportation Research Record, \#1925, TRB, National Research Council, Washington, DC, pp. 1-11, 2005.

5. Balke, K., "Probe-Based Traffic Monitoring Systems with Wireless Location Technology," Transportation Research Record, \#1925, TRB, National Research Council, Washington, DC, pp. 1-11, 2005.

6. Quiroga, C. and D. Bullock, "Determination of Sample Sizes for Travel Time Studies," Institute of Transportation Engineers Journal on the Web, Volume 68, Number 8, pp. 92-98, August 1998.

7. Nanthawichit, C., T. Nakatsuji, and H. Suzuki, "Application of Probe-Vehicle Data for Real-Time Traffic-State Estimation and Short -Term Travel-Time Prediction on a Freeway," Transportation Research Record, \#1855, TRB, National Research Council, Washington, DC, pp. 49-59, 2003.

8. Wasson, J.S., J.R. Sturdevant, D.M. Bullock, "Real-Time Travel Time Estimates Using MAC Address Matching," Institute of Transportation Engineers Journal, ITE, Vol. 78, No. 6, pp. 20-23, June 2008. 


\section{FIGURES}

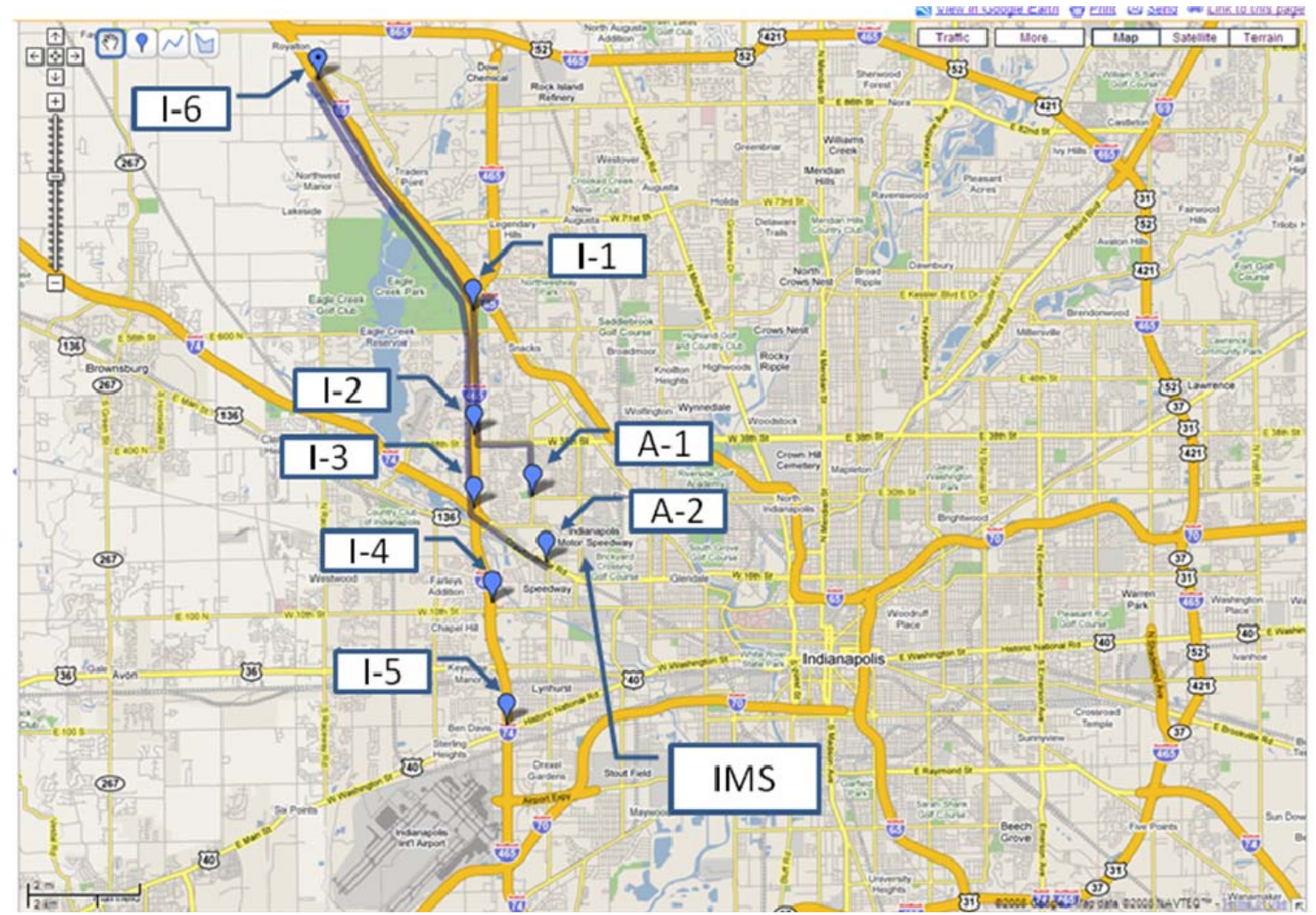

\begin{tabular}{|c|c|c|c|}
\hline Site Code & $\begin{array}{l}\text { Data } \\
\text { Collected } \\
\text { July 18-20, } \\
2008\end{array}$ & $\begin{array}{l}\text { Data } \\
\text { Collected } \\
\text { July 25-27, } \\
2008\end{array}$ & Location \\
\hline $\mathrm{I}-1$ & $\begin{array}{l}\text { MAC } \\
\text { Address }\end{array}$ & $\begin{array}{l}\text { MAC } \\
\text { Address }\end{array}$ & $\begin{array}{l}\text { I-465 (Exit 20) at 165, Median between I-465 } \\
\text { lanes }\end{array}$ \\
\hline $\mathrm{I}-2$ & $\begin{array}{l}\text { MAC } \\
\text { Address }\end{array}$ & $\begin{array}{l}\text { MAC } \\
\text { Address }\end{array}$ & $\begin{array}{l}\text { I-465 (Exit 17) at } 38^{\text {th }} \text { Street, Northwest } \\
\text { Quadrant }\end{array}$ \\
\hline $1-3$ & $\begin{array}{l}\text { MAC } \\
\text { Address, } \\
\text { Speed, and } \\
\text { Volume }\end{array}$ & $\begin{array}{l}\text { MAC } \\
\text { Address, } \\
\text { Speed, and } \\
\text { Volume }\end{array}$ & I-465 (Exit 16) at I74, Northwest Quadrant \\
\hline $1-4$ & & $\begin{array}{l}\text { MAC } \\
\text { Address }\end{array}$ & I-465 (Exit 14) at $10^{\text {th }}$ Street Northeast Quadrant \\
\hline $1-5$ & & $\begin{array}{l}\text { MAC } \\
\text { Address }\end{array}$ & $\begin{array}{l}\text { I-465 (Exit 12) at Washington Street, Northwest } \\
\text { Quadrant }\end{array}$ \\
\hline $1-6$ & & $\begin{array}{l}\text { MAC } \\
\text { Address, } \\
\text { Speed and } \\
\text { Volume }\end{array}$ & I-65 (MM 127.8) \\
\hline A-1 & MAC Address & $\begin{array}{l}\text { MAC } \\
\text { Address }\end{array}$ & $\begin{array}{l}\text { Moller Road at W. } 30^{\text {th }} \text { Street, West side of T- } \\
\text { Intersection }\end{array}$ \\
\hline A-2 & MAC Address & $\begin{array}{l}\text { MAC } \\
\text { Address }\end{array}$ & $\begin{array}{l}\text { North Lyndhurst Drive at Crawfordsville Road, } \\
\text { West approach }\end{array}$ \\
\hline
\end{tabular}

Figure 1: Travel time monitoring stations along principal routes on West side of Indianapolis. 


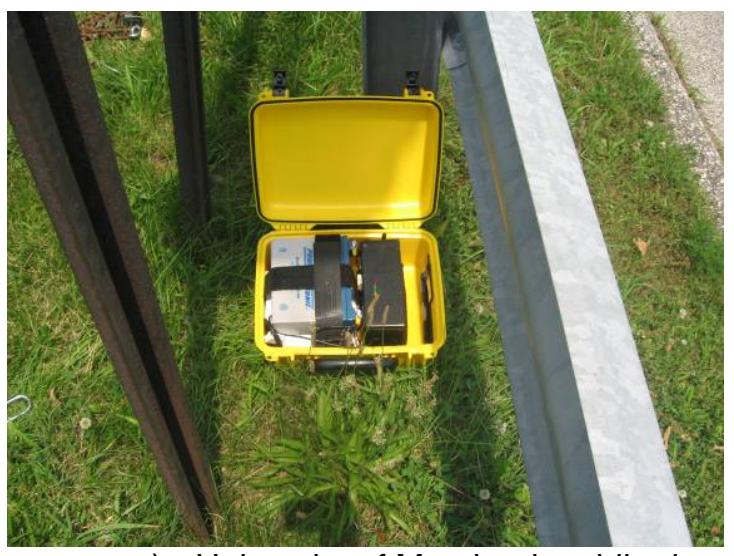

a) University of Maryland mobile data collection equipment at site A-2.

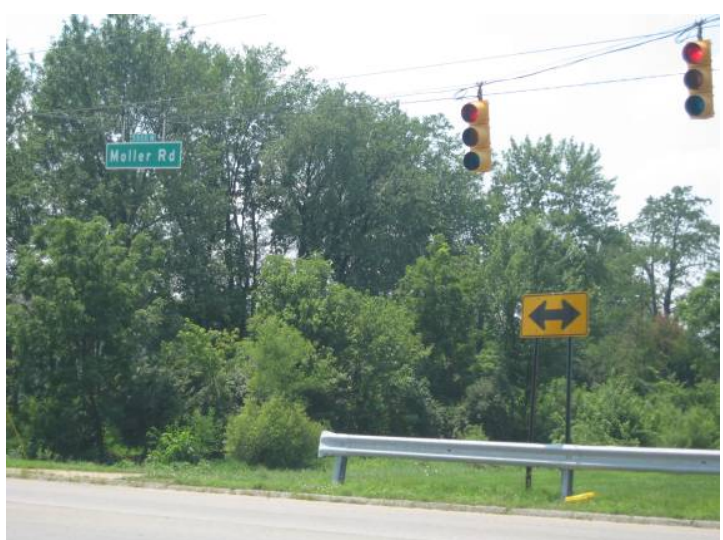

b) Site A-2 mobile equipment installed adjacent to sign.

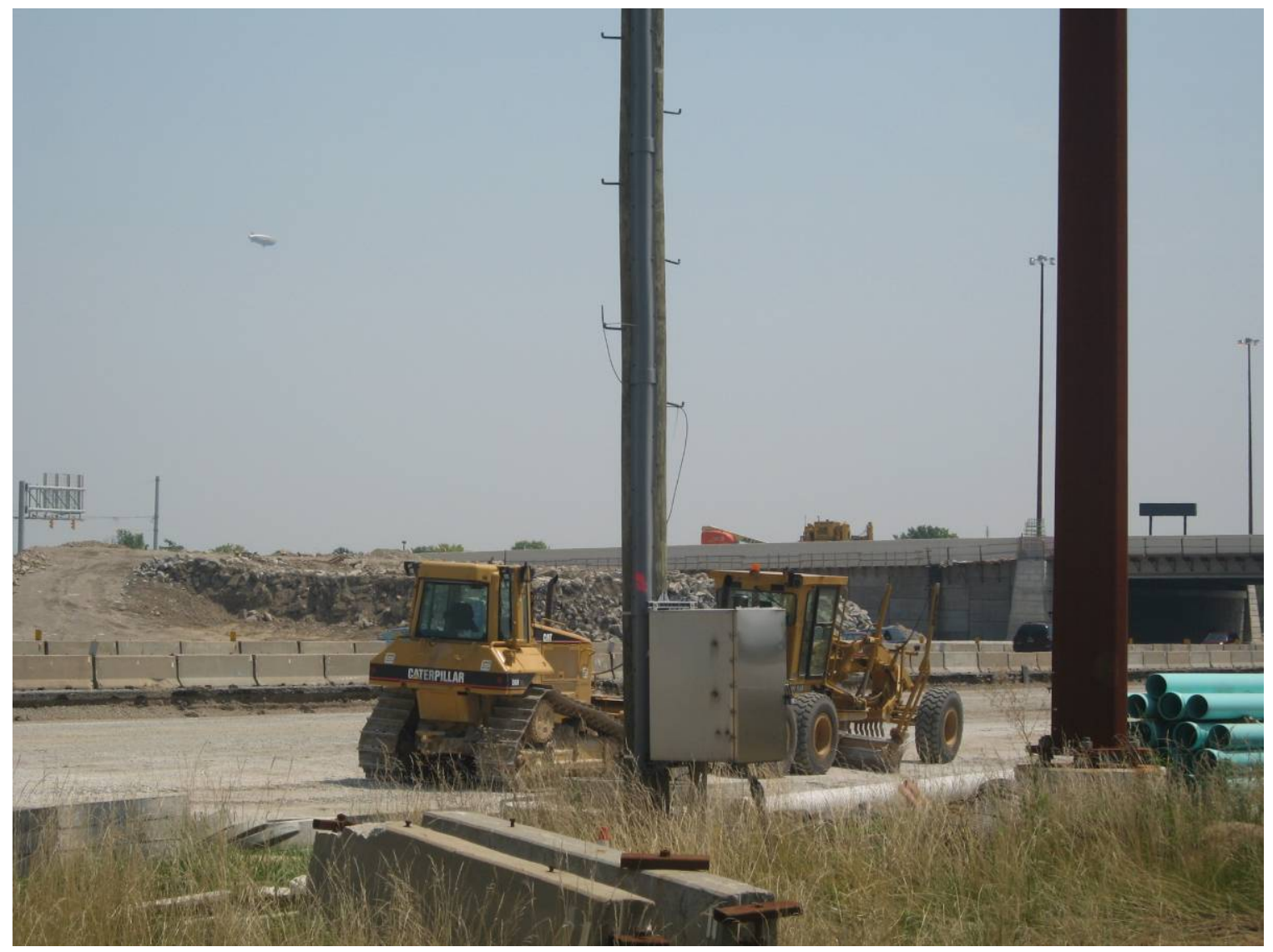

c) INDOT Monitoring Site I-2, adjacent to I-465.

Figure 2: Photographs of data collection equipment at selected sites. 


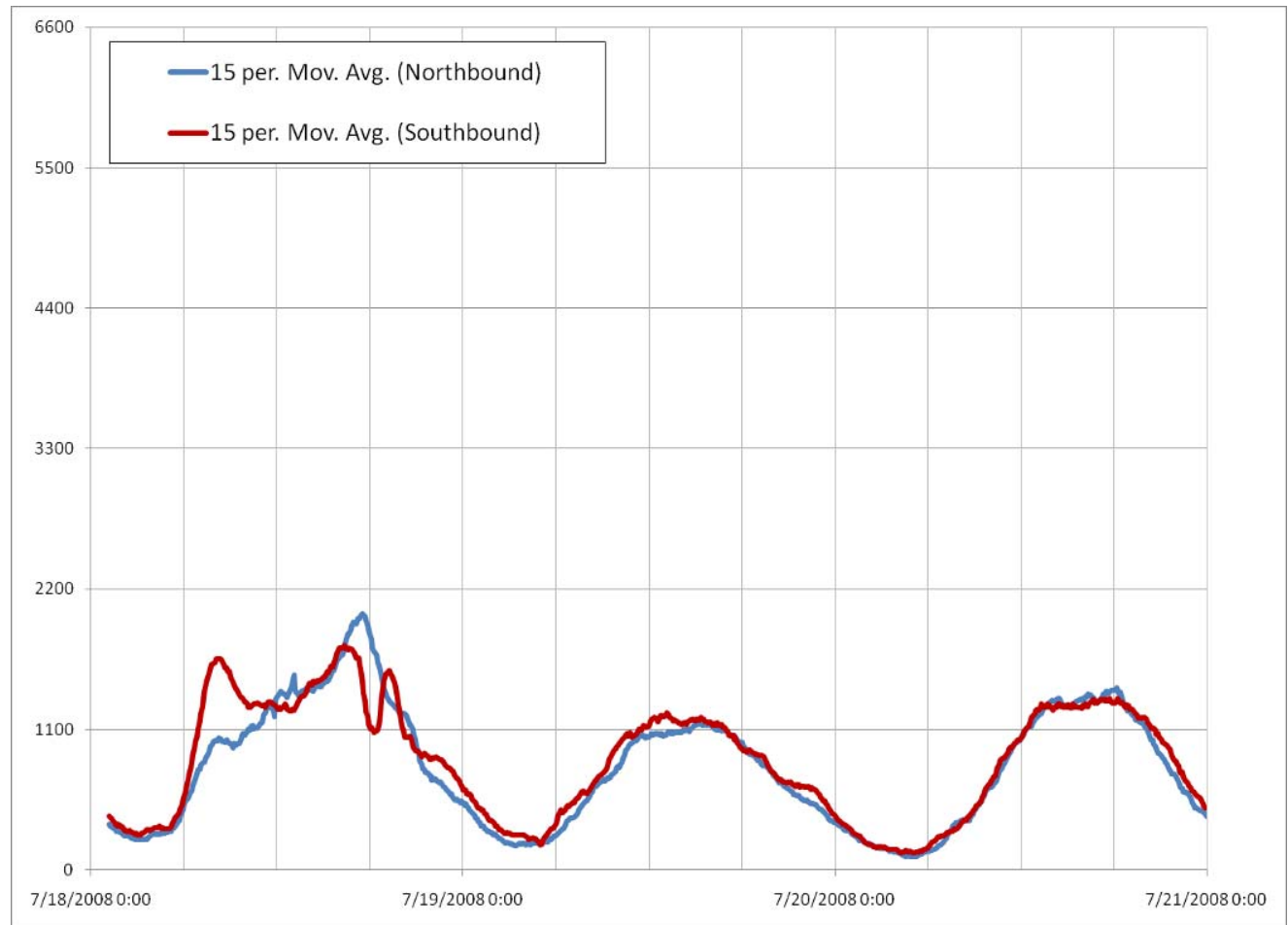

a) July $18-20,2008$

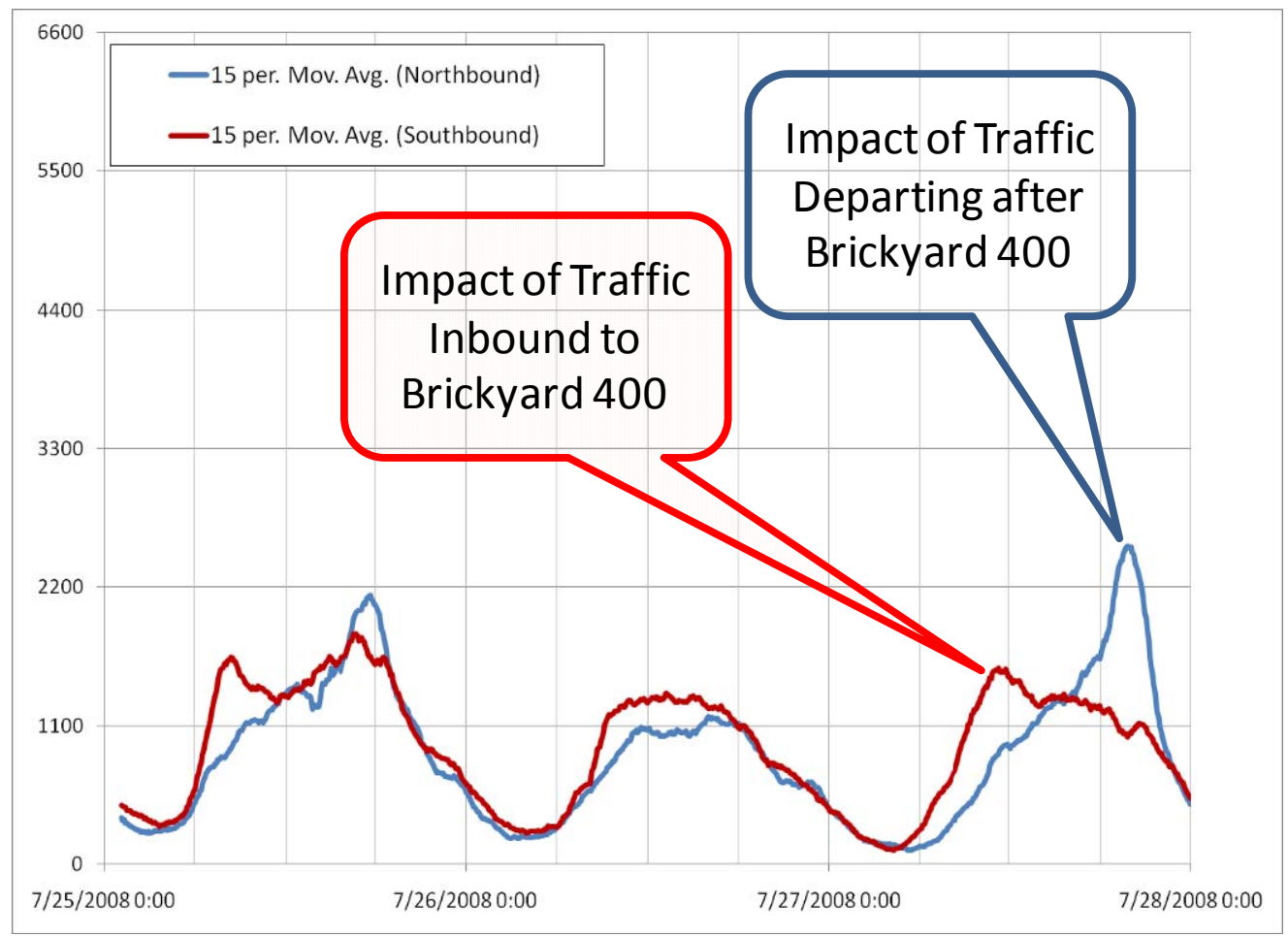

b) July $25-27,2008$

Figure 3: Traffic flow rate (vph) at MM 127.8 on I-65 (Site I-6) where Southbound flow is influenced by Inbound IMS Traffic and Northbound flow is influenced by Outbound IMS Traffic. 


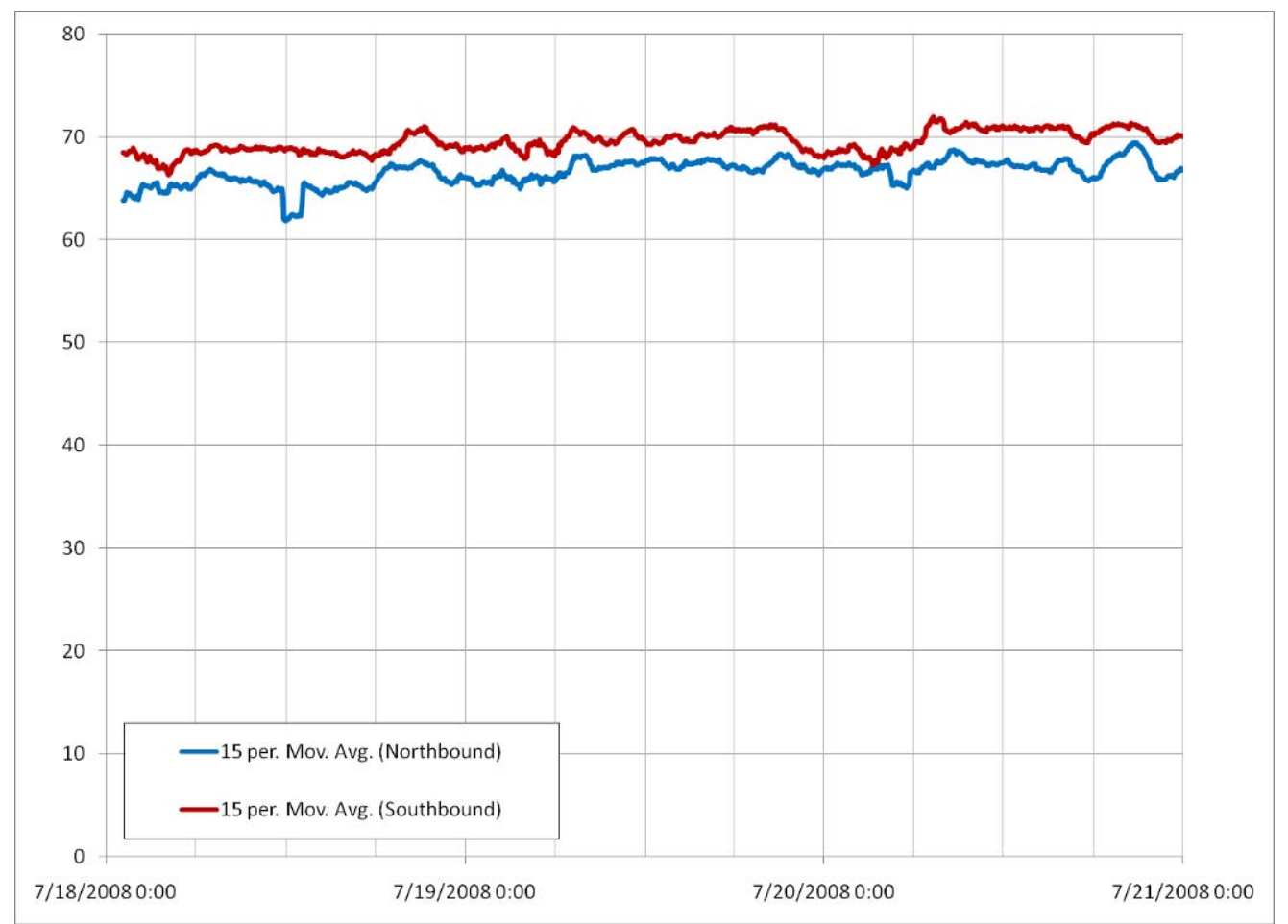

a) July $18-20,2008$

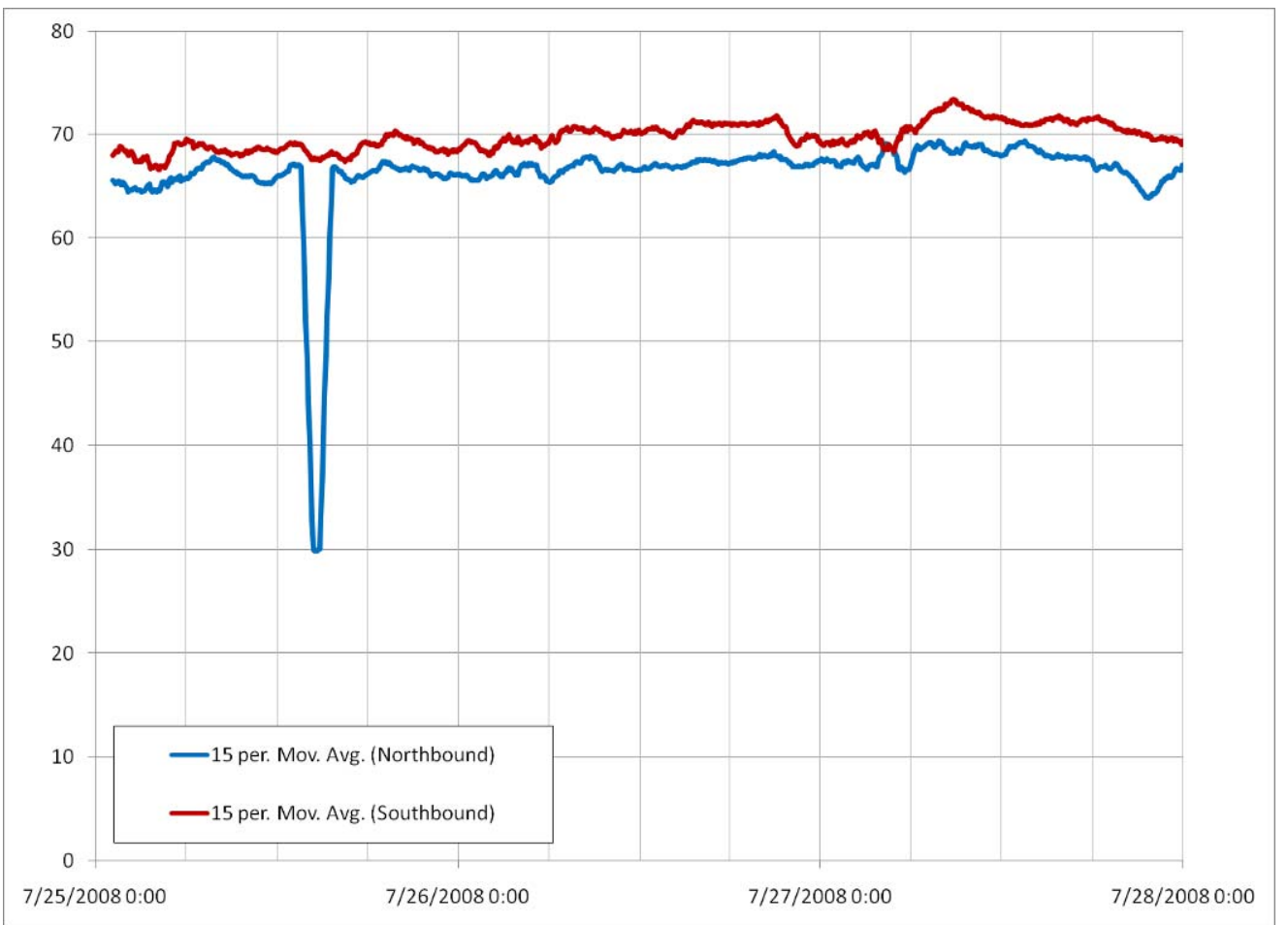

b) July $25-27,2008$

Figure 4: Average speed (mph) at I-65 MM 127.8 


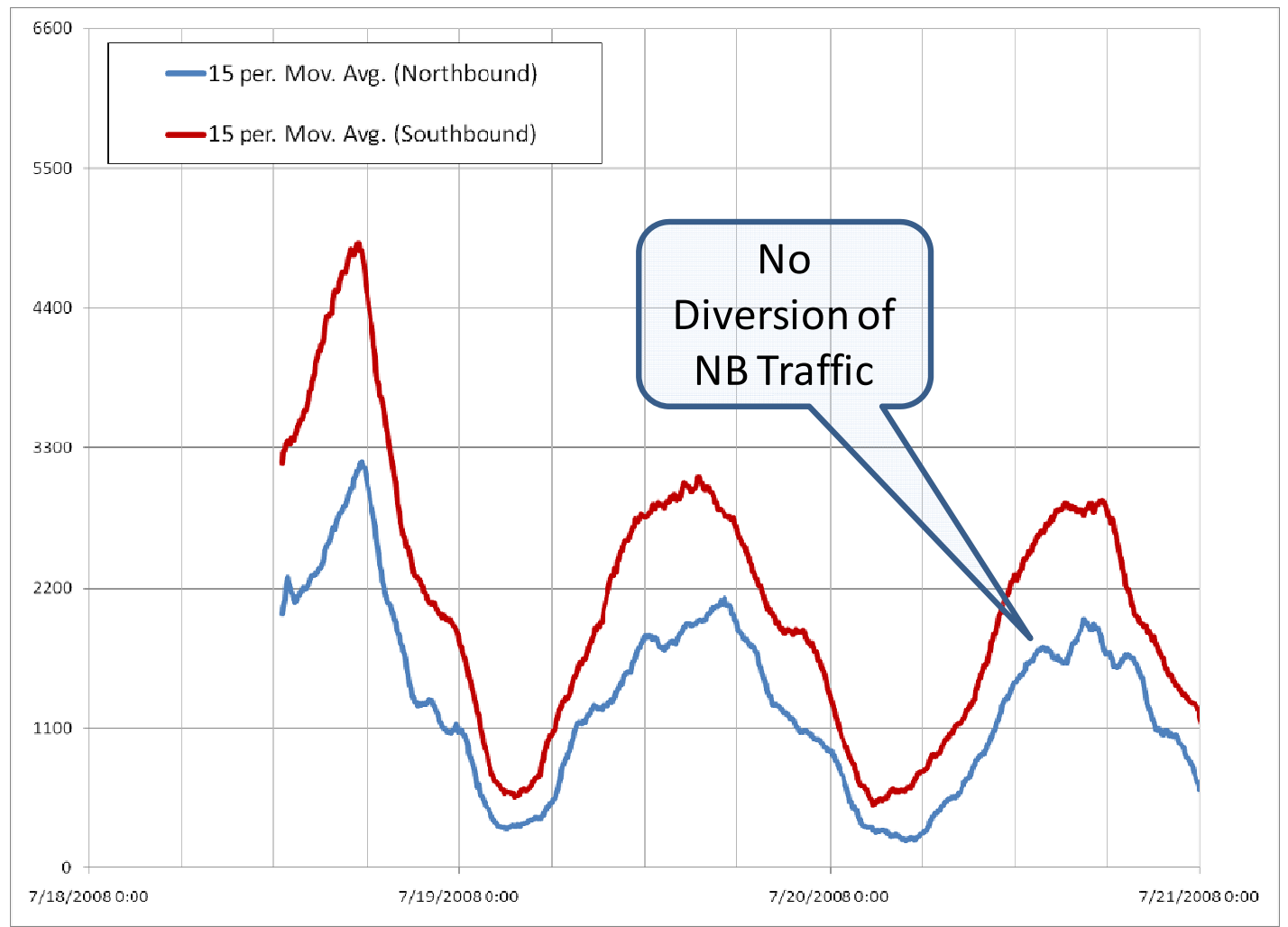

a) July $18-20,2008$

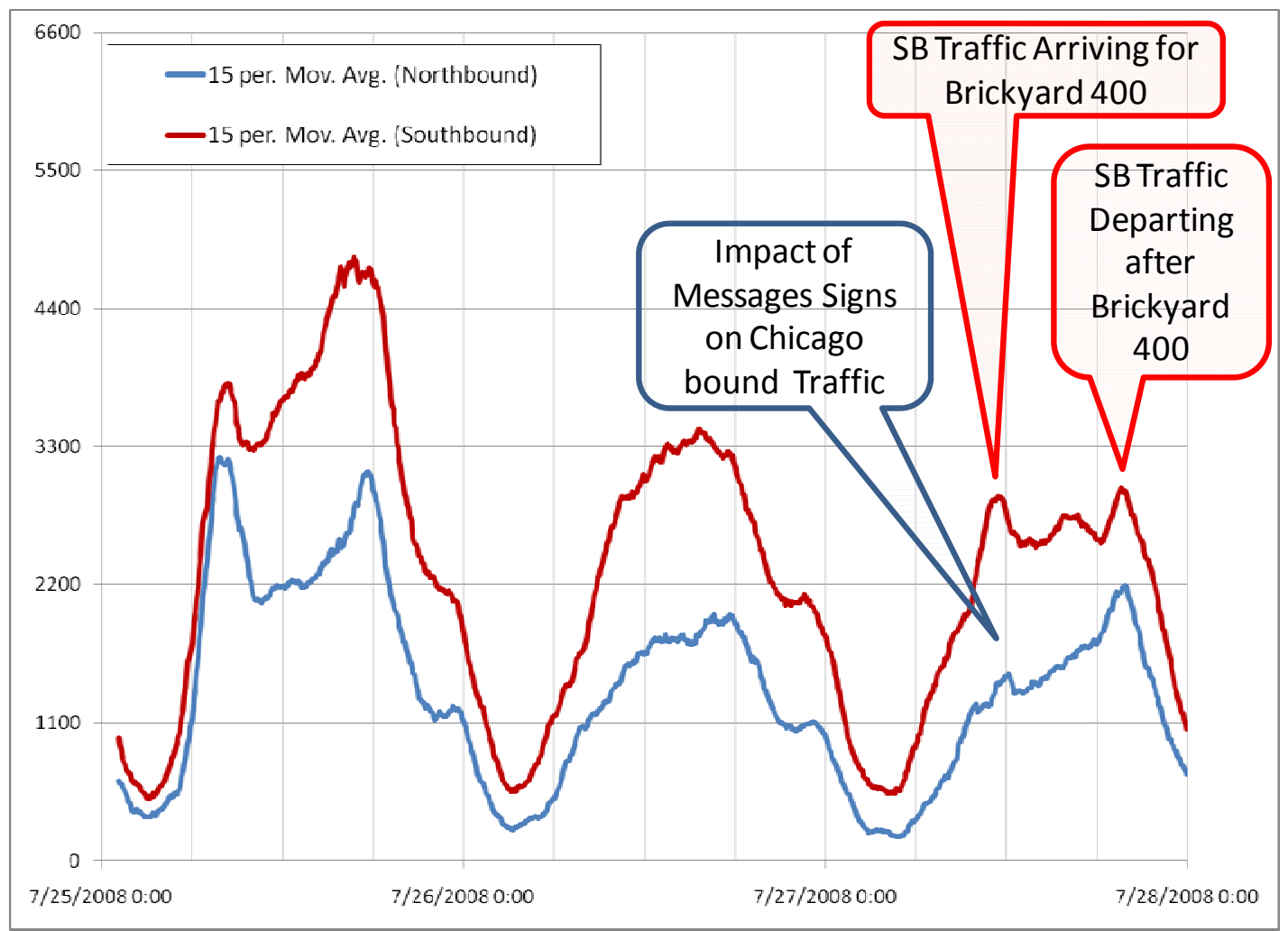

b) July $25-27,2008$

Figure 5: Traffic flow rate (vph) at Exit 16 on I-465 (Site I-3) 


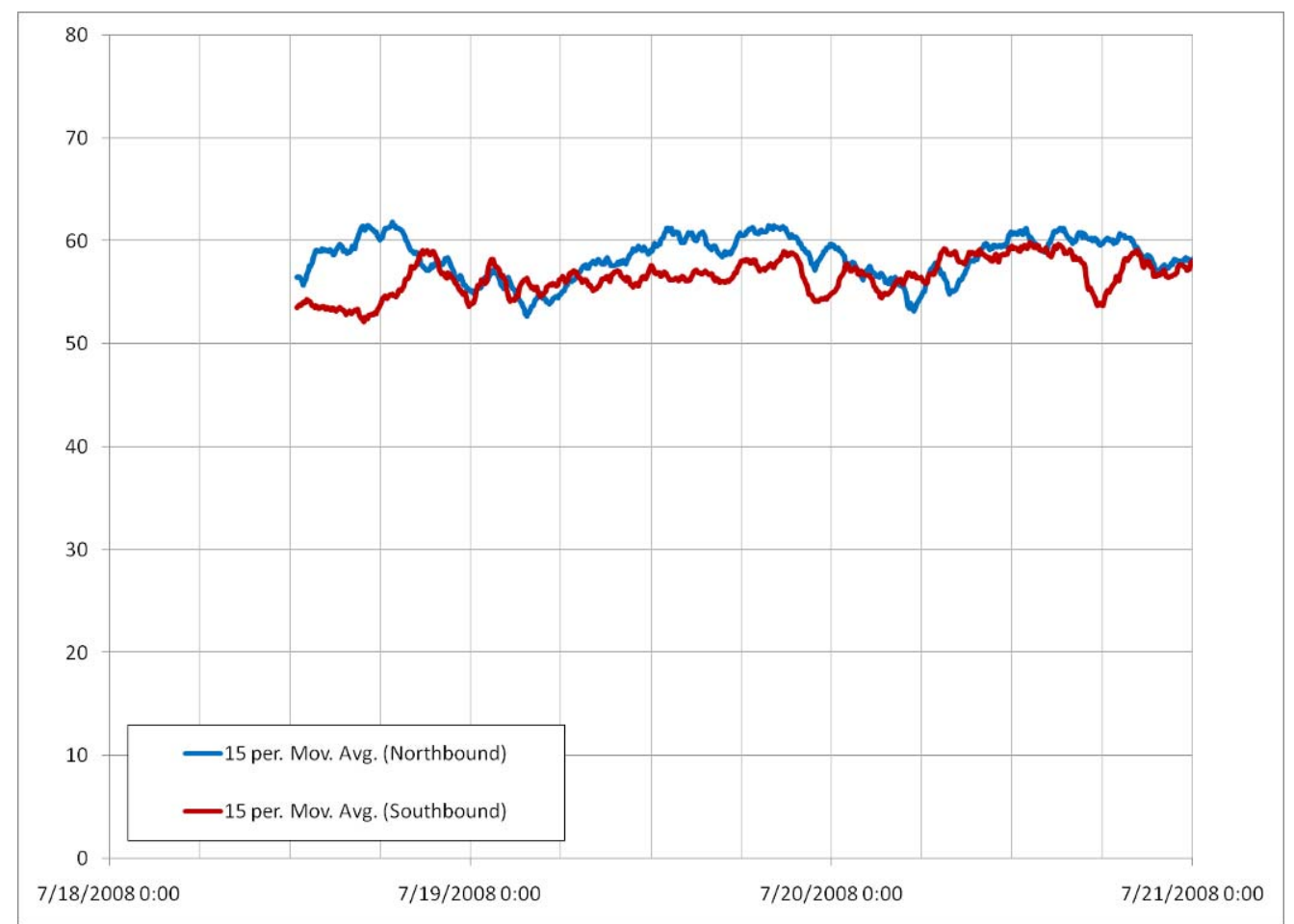

a) July 18-20, 2008

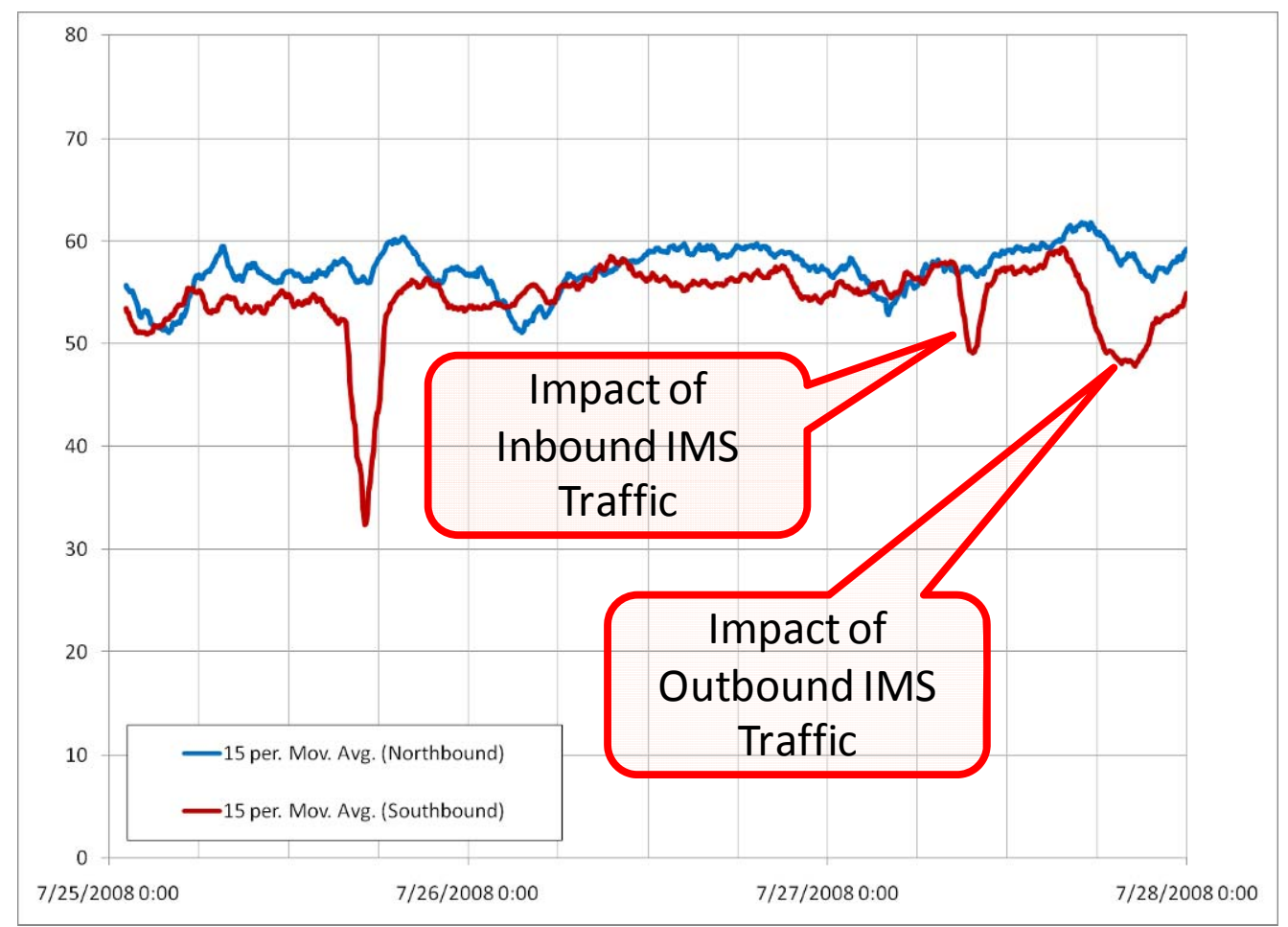

b) July $25-27,2008$

Figure 6: Average speed (mph) at Exit 16 on I-465 (Site I-3) 


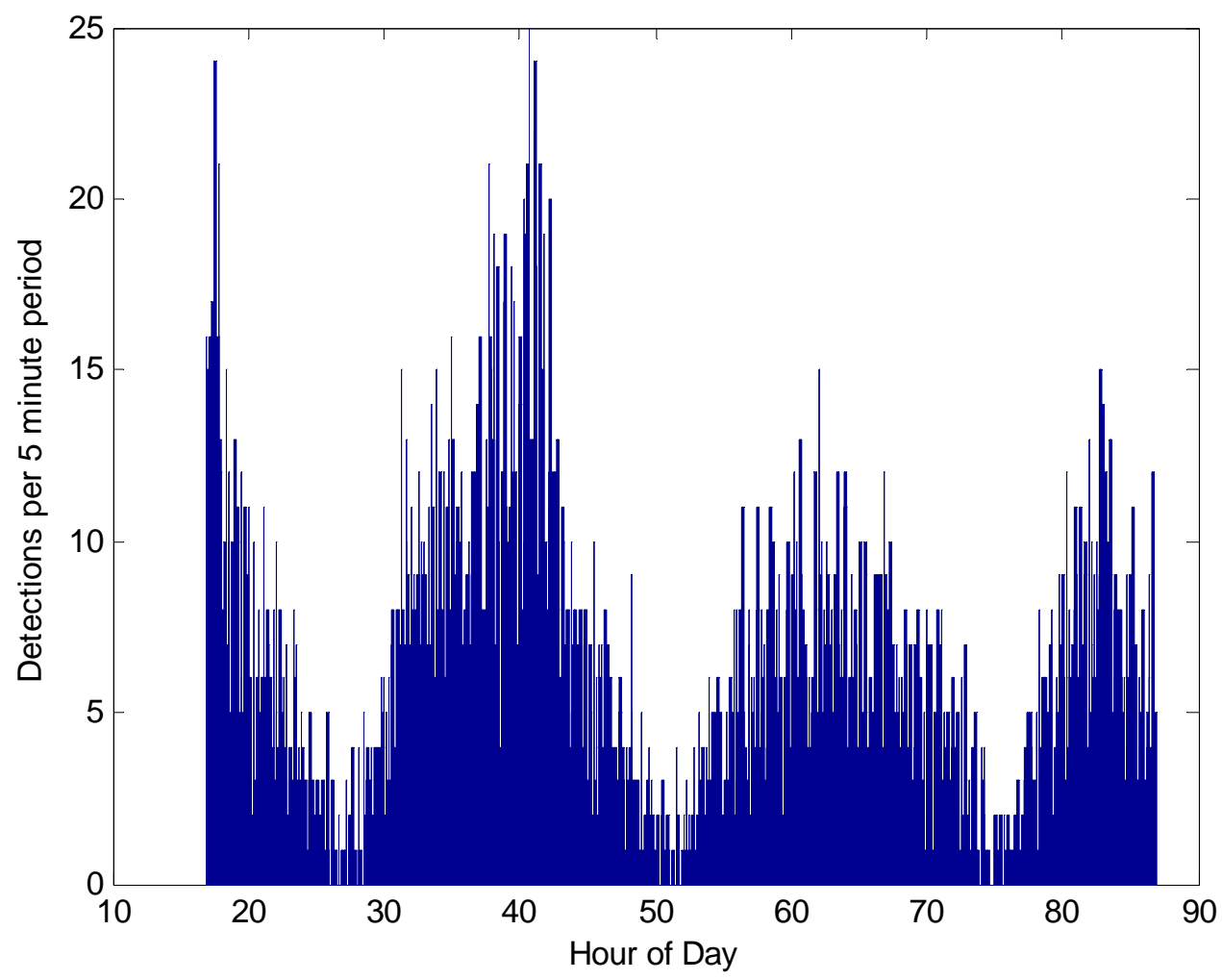

Figure 7: Match Rate from I1 to I2 vs. Time (total matches 5094) for units deployed at 1700 on July 24, 2008 (Hour 17 in plot) and retrieved at 0800 on July 28, 2008 (Hour 87 in plot) 


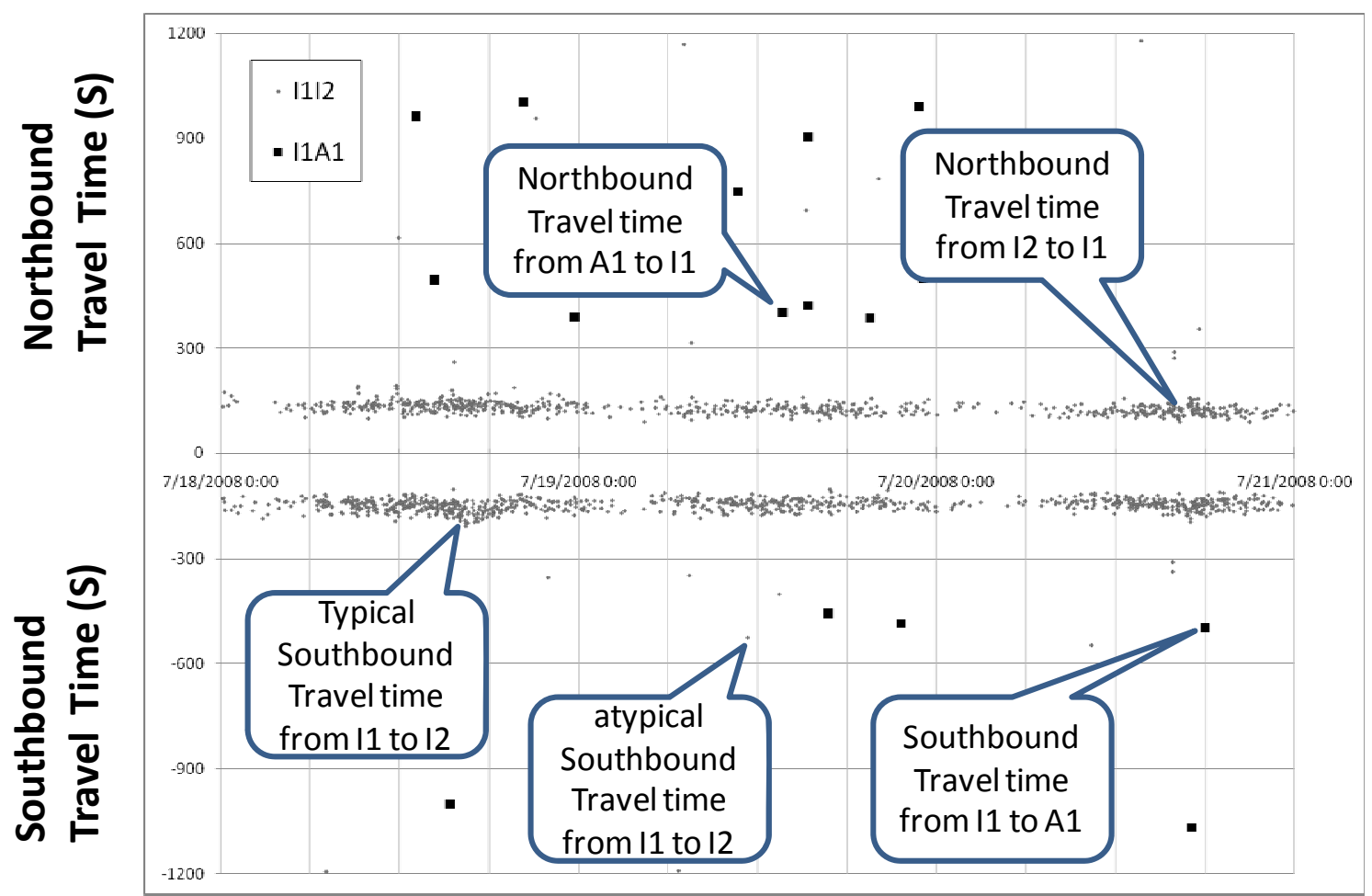

a) July $18-20,2008$

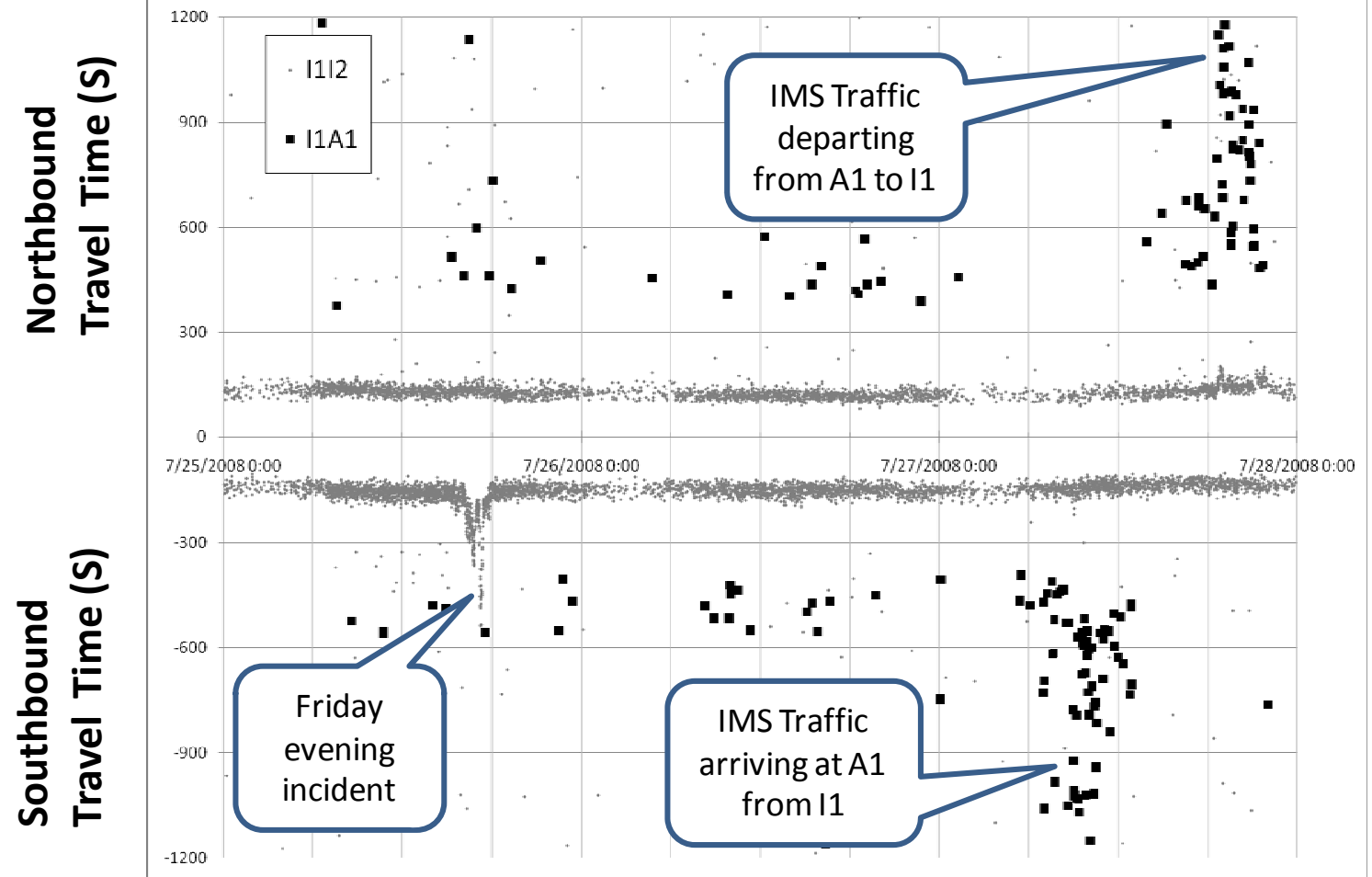

b) July $25-27,2008$

Figure 8: Travel Time Plot: Stations I-1, I-2, A-1 


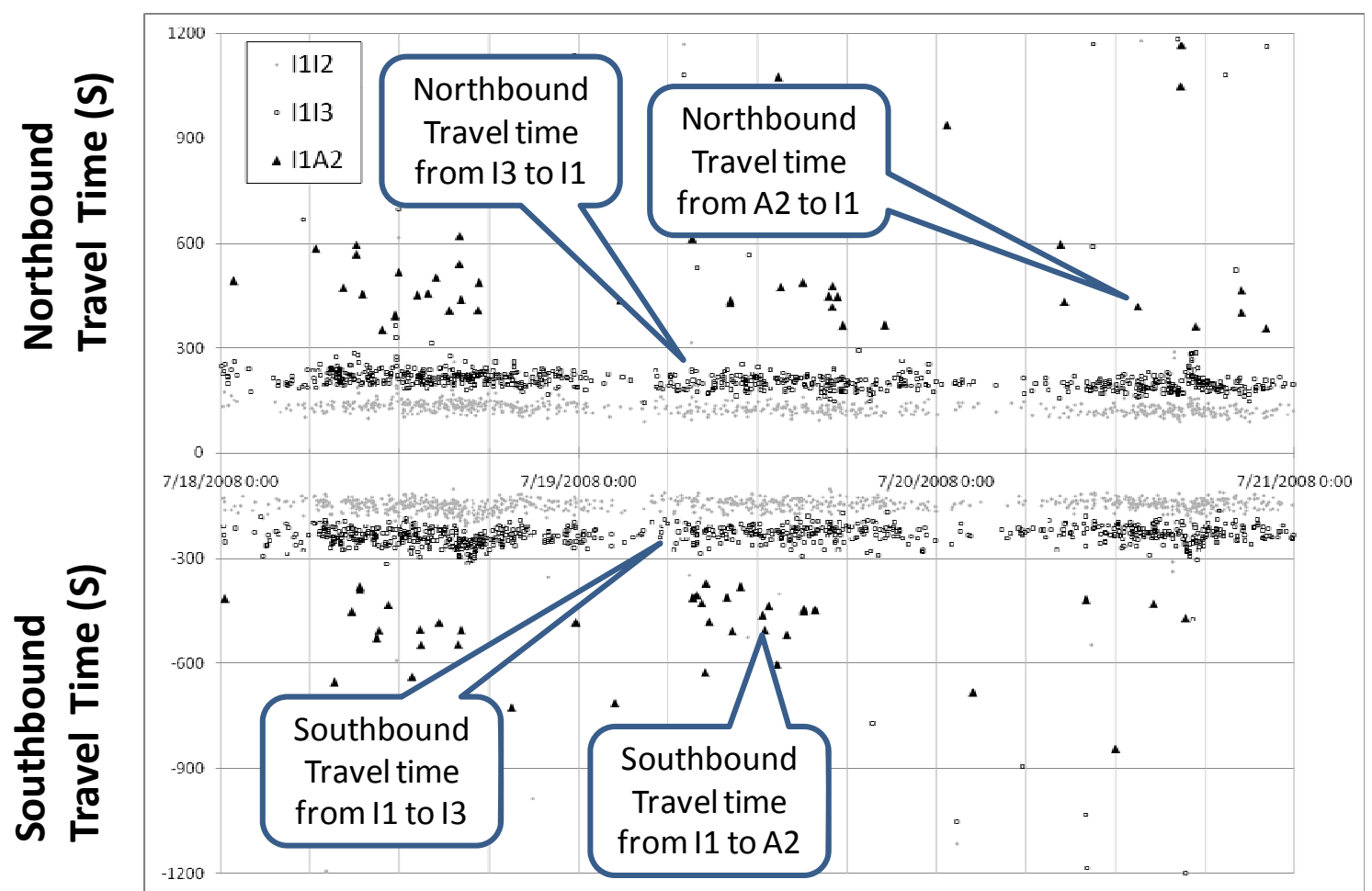

a) July 18-20, 2008

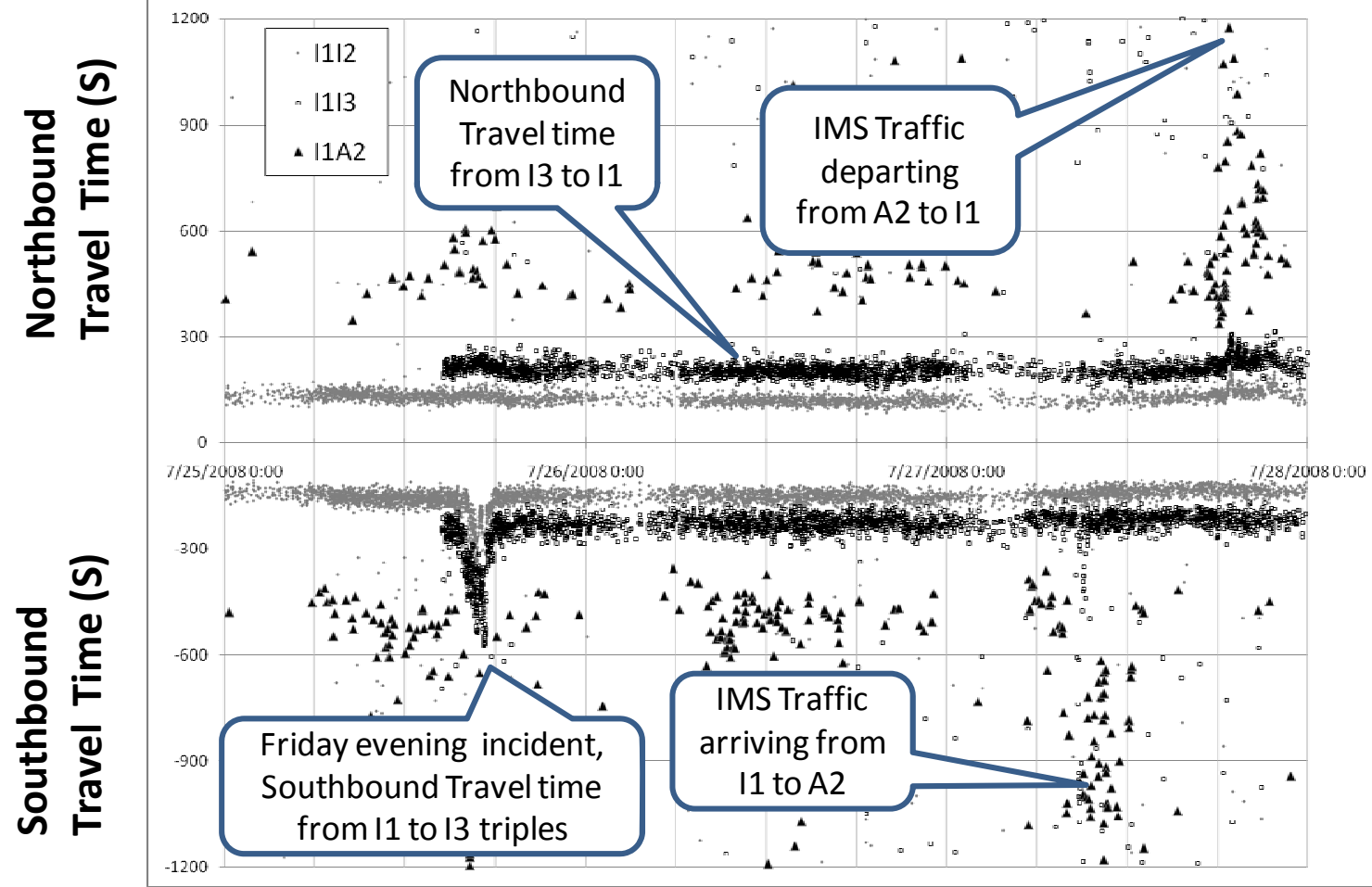

b) July $25-27,2008$

Figure 9: Travel Time Plot: Stations I-1, I-2, I3, A2 


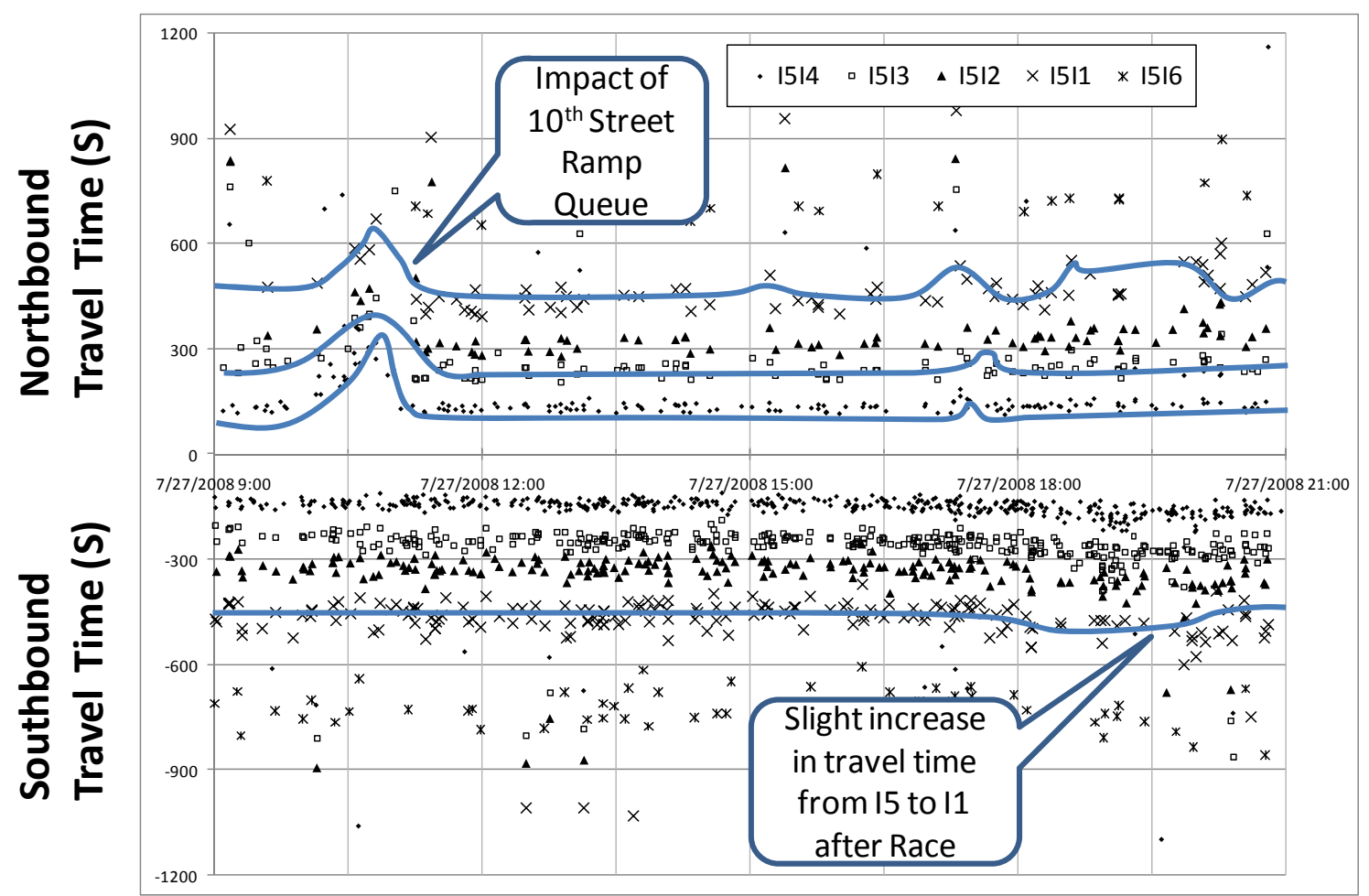

Figure 10: Travel Time Plot: Stations I-5, I-4, I-3, I-2, I-1, I-6 on July 27, 2008 from 0900 to 2100. 


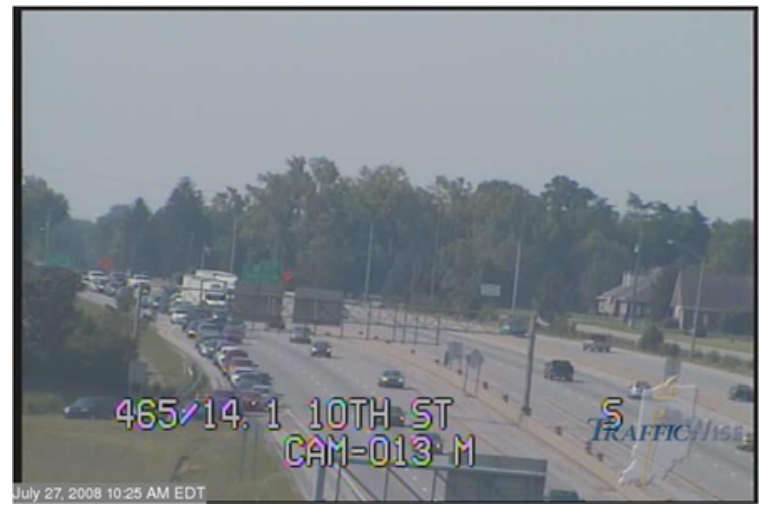

a) 10: 25: Ramp queue causing 2 mile backup on I-465 across all three lanes

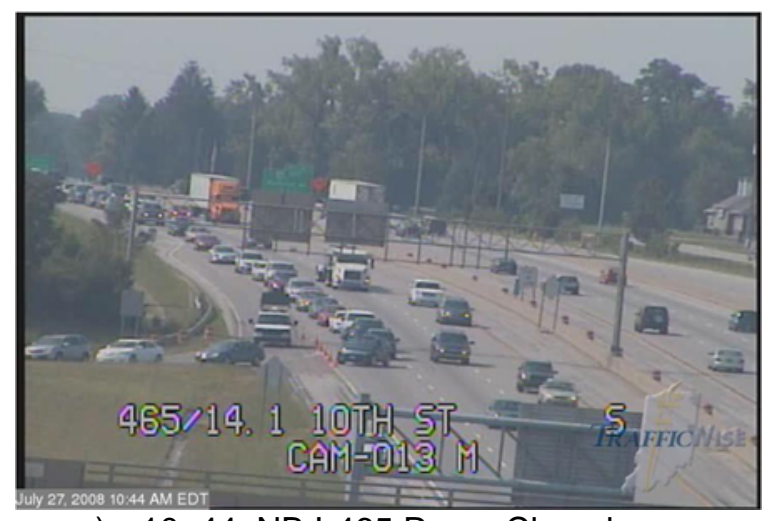

c) 10: 44: NB I-465 Ramp Closed

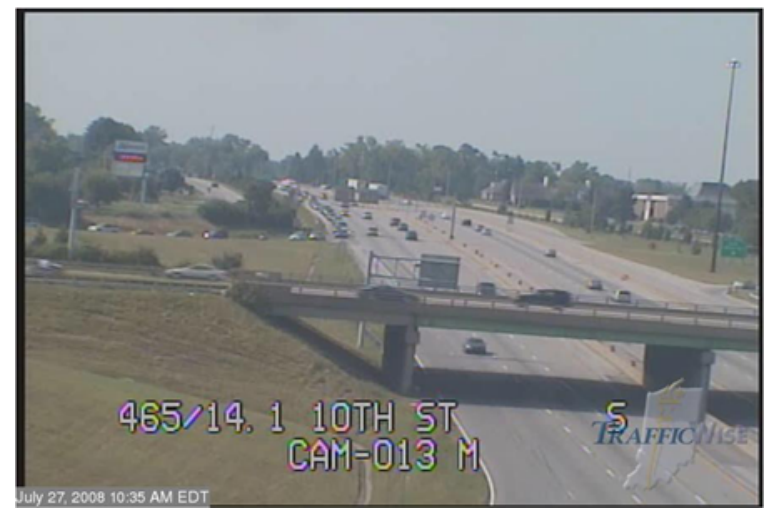

b) 10: 35: NB I-465 flow highly restricted by exit ramp queue

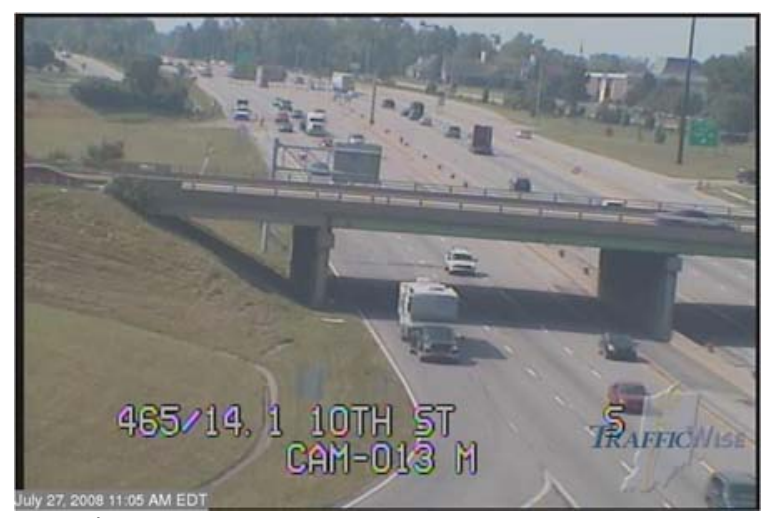

d) 11:05: NB I-465 queue cleared, I-465 freeflowing and ramp reopening

Figure 11: Images of $10^{\text {th }}$ Street Exit Queue and Impact on I-465 


\section{TABLES}

Table 1: Summary of MAC Addresses acquired at study sites.

\begin{tabular}{|l|l|l|l|l|}
\hline & \multicolumn{2}{|l|}{ Sunday July $20^{\text {th }} 2008$} & \multicolumn{2}{l|}{ Sunday July $27^{\text {th }} 2008$} \\
\hline Site Code & Hits & Unique Hits & Hits & Unique Hits \\
\hline I-1 & 3476 & 2499 & 4270 & 3094 \\
\hline I-2 & 4162 & 1826 & 14729 & 2806 \\
\hline I-3 & 4388 & 1951 & 15400 & 3666 \\
\hline I-4 & -- & -- & 16989 & 3367 \\
\hline I-5 & -- & -- & 2918 & 1183 \\
\hline I-6 & -- & -- & 10750 & 2557 \\
\hline A-1 & 2446 & 583 & 4470 & 1179 \\
\hline A-2 & 608 & 399 & 13430 & 1111 \\
\hline
\end{tabular}

Table 2: Example Real-Time Travel Time Data Screen available on mobile data terminals on race day (Station I-3 to I-6)

\begin{tabular}{|c|c|c|c|c|c|c|}
\hline \multirow[b]{2}{*}{ Date } & \multirow[b]{2}{*}{ Last Data } & & \multicolumn{4}{|c|}{ Computed Travel Time for } \\
\hline & & & Size & Matching & g MAC & Adddresses \\
\hline $2008-07-27$ & $19: 55: \odot \odot$ & 2 & $08: 19$ & $08: 25$ & & \\
\hline $2 \odot \odot 8-\odot 7-27$ & $19: 5 \odot: \odot \odot$ & 2 & ๑8: 07 & ๑8:०9 & & \\
\hline $2 \odot \odot 8-\odot 7-27$ & $19: 45: \odot \odot$ & 3 & $\odot 8: 36$ & $\odot 8: 44$ & $52: 30$ & \\
\hline $20 \odot 8-\odot 7-27$ & $19: 4 \odot: \odot \odot$ & 1 & $\odot 8: 32$ & & & \\
\hline $2 \odot \odot 8-\odot 7-27$ & $19: 35: \odot \odot$ & 1 & $08: 49$ & & & \\
\hline $20 \odot 8-\odot 7-27$ & $19: 3 \odot: \odot \odot$ & 3 & $08: 54$ & $09: 35$ & $09: 44$ & \\
\hline $20 \odot 8-\odot 7-27$ & $19: 25: \odot \odot$ & 2 & $08: 05$ & $86: 48$ & & \\
\hline $20 \odot 8-\odot 7-27$ & $19: 20: \odot \odot$ & $\odot$ & & & & \\
\hline $2 \odot \odot 8-\odot 7-27$ & $19: 15: \odot \odot$ & $\odot$ & & & & \\
\hline $20 \odot 8-\odot 7-27$ & $19: 10: \odot \odot$ & 2 & $08: 31$ & $142: 22$ & & \\
\hline $20 \odot 8-\odot 7-27$ & 19:०5:๑९ & 1 & $138: 25$ & & & \\
\hline $2 \odot \odot 8-\odot 7-27$ & 19:०९:०๑ & 0 & & & & \\
\hline $20 \odot 8-\odot 7-27$ & $18: 55: \odot \odot$ & $\odot$ & & & & \\
\hline $20 \odot 8-\odot 7-27$ & $18: 5 \odot: \odot \odot$ & 4 & $08: 10$ & $08: 18$ & $\odot 8: 55$ & $41: 21$ \\
\hline $2 \odot \odot 8-\odot 7-27$ & $18: 45: \odot \odot$ & 1 & $08: 34$ & & & \\
\hline $20 \odot 8-\odot 7-27$ & $18: 4 \odot: \odot \odot$ & 3 & $07: 52$ & $\odot 8: 23$ & $08: 25$ & \\
\hline $20 \odot 8-\odot 7-27$ & $18: 35: \odot \odot$ & 1 & $08: 21$ & & & \\
\hline $20 \odot 8-\odot 7-27$ & $18: 30: \odot \odot$ & 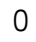 & & & & \\
\hline $20 \odot 8-\odot 7-27$ & $18: 25: \odot \odot$ & 4 & $07: 54$ & $07: 59$ & $\odot 8: \odot \odot$ & $09: 16$ \\
\hline $20 \odot 8-\odot 7-27$ & $18: 20: \odot \odot$ & 1 & $08: 53$ & & & \\
\hline $20 \odot 8-\odot 7-27$ & $18: 15: \odot \odot$ & 1 & $08: 53$ & & & \\
\hline
\end{tabular}


Table 3: MAC address Origin Destination Table for July 27, 2008 10:00- 14:00

\begin{tabular}{|l|l|l|l|l|l|l|l|l|}
\hline & \multicolumn{7}{|c|}{ Destination Site Code } \\
\hline $\begin{array}{l}\text { Origin } \\
\text { Site } \\
\text { Code }\end{array}$ & I-6 & I-1 & I-2 & I-3 & I-4 & I-5 & A-1 & A-2 \\
\hline I-6 & & 32 & 29 & 28 & 27 & 9 & 0 & 0 \\
\hline I-1 & 88 & & 158 & 160 & 151 & 37 & 2 & 1 \\
\hline I-2 & 99 & 368 & & 159 & 135 & 31 & 2 & 2 \\
\hline$I-3$ & 70 & 259 & 292 & & 236 & 43 & 5 & 10 \\
\hline I-4 & 43 & 184 & 207 & 264 & & 79 & 4 & 7 \\
\hline I-5 & 22 & 73 & 84 & 104 & 167 & & 2 & 4 \\
\hline A-1 & 12 & 37 & 35 & 34 & 35 & 1 & & 16 \\
\hline A-2 & 26 & 53 & 55 & 63 & 58 & 7 & 6 & \\
\hline
\end{tabular}

a) Number of Matches

\begin{tabular}{|l|l|l|l|l|l|l|l|l|}
\hline & \multicolumn{7}{|c|}{ Destination Site Code } \\
\hline $\begin{array}{l}\text { Origin } \\
\begin{array}{l}\text { Site } \\
\text { Code }\end{array}\end{array}$ & I-6 & I-1 & I-2 & I-3 & I-4 & I-5 & A-1 & A-2 \\
\hline I-6 & & 251 & 362 & 429 & 517 & 653 & 0 & 0 \\
\hline I-1 & 231 & & 95 & 162 & 258 & 394 & 559 & 515 \\
\hline I-2 & 334 & 106 & & 58 & 153 & 277 & 684 & 367 \\
\hline I-3 & 403 & 171 & 64 & & 86 & 206 & 438 & 170 \\
\hline I-4 & 491 & 264 & 143 & 70 & & 112 & 551 & 279 \\
\hline I-5 & 615 & 405 & 281 & 208 & 113 & & 704 & 470 \\
\hline A-1 & 820 & 477 & 333 & 373 & 421 & 859 & & 233 \\
\hline A-2 & 905 & 460 & 335 & 256 & 258 & 584 & 719 & \\
\hline
\end{tabular}

b) Minimum travel time (in seconds)

\begin{tabular}{|l|l|l|l|l|l|l|l|l|}
\hline & \multicolumn{7}{|c|}{ Destination Site Code } \\
\hline $\begin{array}{l}\text { Origin } \\
\text { Site } \\
\text { Code }\end{array}$ & $\mathrm{I}-6$ & $\mathrm{I}-1$ & $\mathrm{I}-2$ & $\mathrm{I}-3$ & $\mathrm{I}-4$ & $\mathrm{I}-5$ & $\mathrm{~A}-1$ & $\mathrm{~A}-2$ \\
\hline $\mathrm{I}-6$ & & 430 & 666 & 689 & 757 & 995 & 0 & 0 \\
\hline $\mathrm{I}-1$ & 342 & & 359 & 449 & 484 & 872 & 1180 & 515 \\
\hline $\mathrm{I}-2$ & 451 & 235 & & 354 & 404 & 574 & 1168 & 448 \\
\hline $\mathrm{I}-3$ & 556 & 385 & 253 & & 306 & 569 & 750 & 279 \\
\hline $\mathrm{I}-4$ & 672 & 569 & 397 & 265 & & 451 & 616 & 370 \\
\hline $\mathrm{I}-5$ & 833 & 601 & 470 & 349 & 208 & & 707 & 538 \\
\hline A-1 & 1212 & 773 & 762 & 790 & 968 & 859 & & 594 \\
\hline A-2 & 1431 & 1086 & 1027 & 872 & 1047 & 2065 & 1328 & \\
\hline
\end{tabular}

c) Mean travel time (in seconds) 
Table 4: MAC address Origin Destination Table for July 27, 2008 1800-2200

\begin{tabular}{|l|l|l|l|l|l|l|l|l|}
\hline & \multicolumn{7}{|c|}{ Destination Site Code } \\
\hline $\begin{array}{l}\text { Origin } \\
\text { Site } \\
\text { Code }\end{array}$ & $\mathrm{I}-6$ & $\mathrm{I}-1$ & $\mathrm{I}-2$ & $\mathrm{I}-3$ & $\mathrm{I}-4$ & $\mathrm{I}-5$ & $\mathrm{~A}-1$ & $\mathrm{~A}-2$ \\
\hline $\mathrm{I}-6$ & & 119 & 97 & 81 & 55 & 13 & 18 & 14 \\
\hline $\mathrm{I}-1$ & 58 & & 359 & 328 & 252 & 30 & 49 & 56 \\
\hline $\mathrm{I}-2$ & 66 & 263 & & 345 & 240 & 41 & 32 & 48 \\
\hline $\mathrm{I}-3$ & 51 & 204 & 258 & & 325 & 45 & 26 & 138 \\
\hline $\mathrm{I}-4$ & 46 & 185 & 234 & 466 & & 61 & 27 & 64 \\
\hline $\mathrm{I}-5$ & 16 & 41 & 58 & 142 & 172 & & 8 & 25 \\
\hline A-1 & 0 & 1 & 3 & 1 & 3 & 0 & & 1 \\
\hline A-2 & 1 & 2 & 2 & 5 & 3 & 0 & 15 & \\
\hline
\end{tabular}

a) Number of Matches

\begin{tabular}{|l|l|l|l|l|l|l|l|l|}
\hline & \multicolumn{7}{|c|}{ Destination Site Code } \\
\hline $\begin{array}{l}\text { Origin } \\
\begin{array}{l}\text { Site } \\
\text { Code }\end{array}\end{array}$ & $\mathrm{I}-6$ & $\mathrm{I}-1$ & $\mathrm{I}-2$ & $\mathrm{I}-3$ & $\mathrm{I}-4$ & $\mathrm{I}-5$ & $\mathrm{~A}-1$ & $\mathrm{~A}-2$ \\
\hline $\mathrm{I}-6$ & & 256 & 384 & 460 & 557 & 691 & 820 & 605 \\
\hline $\mathrm{I}-1$ & 241 & & 112 & 183 & 275 & 410 & 437 & 337 \\
\hline $\mathrm{I}-2$ & 345 & 104 & & 64 & 158 & 291 & 302 & 219 \\
\hline $\mathrm{I}-3$ & 422 & 166 & 64 & & 77 & 218 & 392 & 140 \\
\hline $\mathrm{I}-4$ & 517 & 253 & 147 & 80 & & 118 & 510 & 270 \\
\hline $\mathrm{I}-5$ & 668 & 393 & 301 & 222 & 132 & & 700 & 427 \\
\hline A-1 & - & 2063 & 1085 & 1335 & 1192 & - & & 203 \\
\hline A-2 & 712 & 449 & 318 & 187 & 270 & - & 142 & \\
\hline
\end{tabular}

b) Minimum Travel Time (in seconds)

\begin{tabular}{|l|l|l|l|l|l|l|l|l|}
\hline & \multicolumn{7}{|c|}{ Destination Site Code } \\
\hline $\begin{array}{l}\text { Origin } \\
\begin{array}{l}\text { Site } \\
\text { Code }\end{array}\end{array}$ & $\mathrm{I}-6$ & $\mathrm{I}-1$ & $\mathrm{I}-2$ & $\mathrm{I}-3$ & $\mathrm{I}-4$ & $\mathrm{I}-5$ & $\mathrm{~A}-1$ & $\mathrm{~A}-2$ \\
\hline $\mathrm{I}-6$ & & 287 & 442 & 593 & 662 & 1165 & 1369 & 1193 \\
\hline $\mathrm{I}-1$ & 328 & & 239 & 373 & 502 & 860 & 1002 & 809 \\
\hline $\mathrm{I}-2$ & 420 & 238 & & 229 & 340 & 778 & 979 & 635 \\
\hline $\mathrm{I}-3$ & 544 & 449 & 269 & & 291 & 637 & 895 & 582 \\
\hline $\mathrm{I}-4$ & 652 & 524 & 376 & 239 & & 437 & 1197 & 734 \\
\hline $\mathrm{I}-5$ & 774 & 498 & 449 & 362 & 243 & & 1037 & 1037 \\
\hline A-1 & - & 2063 & 1963 & 1335 & 1553 & - & & 203 \\
\hline A-2 & 712 & 462 & 324 & 361 & 1016 & - & 1009 & \\
\hline
\end{tabular}

c) Mean Travel Time (in seconds) 